\title{
Penggunaan Media Video dalam Pembelajaran Managemen Pemasaran untuk Meningkatkan Pemahaman Mahasiswa di Masa Pandemi Covid-19
}

\author{
Natoil \\ STIE Semarang \\ natoil@stiesmarang.ac.id
}

\begin{abstract}
This study aims to describe the use of video media in marketing management courses to improve understanding of class $A$ students of the STIE Semarang Management Study Program for the 2020/2021 Academic Year. This type of research is a classroom action research consisting of 2 cycles. Each of the cycles in this study consisted of planning, implementing, observing and reflecting. This research was conducted on class $A$ students who took marketing management courses at the STIE Semarang Management Study Program in the Academic Year 2020/2021. This research data collection technique using observation, documentation, interviews and tests. The results showed that the completeness value of class $A$ in pre-cycle learning activities was $60 \%$ of students. In the first cycle it increased to $80 \%$ of student completeness and increased again in the second cycle to $90 \%$ of students completing the predetermined KKM, namely 70 with classical indicators of $75 \%$ of students being said to be successful. So it can be said that the use of video media can increase understanding of the marketing management course in class A students of the STIE Semarang Management Study Program.
\end{abstract}

Keywords: video media; marketing management; understanding; covid-19

\section{ABSTRAK}

Penelitian ini bertujuan untuk mendeskripsikan penggunaan media video dalam mata kuliah managemen pemasaran untuk meningkatkan pemahaman mahasiswa kelas A Prodi Managemen STIE Semarang Tahun Akademik 2020/2021. Jenis penelitian ini penelitian tindakan kelas yang terdiri dari 2 siklus. Setiap masing-masing siklus dalam penelitian ini terdiri dari perencanaan, pelaksanaan, observasi dan refleksi. Penelitian ini dilaksanakan pada mahasiswa kelas A yang mengambil mata kuliah managemen pemasaran di Prodi Managemen STIE Semarang Tahun Akademik 2020/2021. Teknik pengumpulan data penelitian ini menggunakan observasi, dokumentasi, wawancara dan tes. Hasil penelitian menunjukkan nilai ketuntasan kelas A pada kegiatan pembelajaran pra siklus $60 \%$ mahasiswa. Pada siklus I meningkat menjadi $80 \%$ ketuntasan mahasiswa dan meningkat lagi pada siklus II menjadi $90 \%$ mahasiswa tuntas dari KKM yang telah ditentukan yaitu 70 dengan indikator klasikal 75\% mahasiswa tuntas dikatakan berhasil. Sehingga bisa dikatakan penggunaan media video dapat meningkatka pemahaman mata kuliah managemen pemasaran pada mahasiswa kelas A Prodi Managemen STIE Semarang.

Kata Kunci: media video; managemen pemasaran; pemahaman; covid-19

Submitted May 04, 2021 | Revised May 21, 2021 | Accepted May 24, 2021

\section{Pendahuluan}

Pelaksanaan pembelajaran managemen pemasaran di Prodi Managemen STIE Semarang selama masa pandemi covid- 19 menggunakan berbagai media salah satunya media video. Kondisi pandemi covid-19 pendidik dituntut kreatif menggunnakan media pembelajaran berbasis teknologi (Darmuki, 2020). Era globalisasi saat ini selalu memperkenalkan kemajuan teknologi-teknologi canggih diberbagai bidang terhadap kehidupan bermasyarakat, membantu dalam perkembangan ilmu pengetahuan dan teknologi untuk mengolah sumber daya yang ada salah satunya dunia pendidikan (Mayer, 2001). Kemajuan tekonologi di Indonesia cukup besar pengaruhnya terhadap perkembangan pendididkan, sehingga lembaga pendidikan berupaya untuk menunjang proses pembelajaran dengan menggunakan teknologi yang ada. Namun faktanya, saat ini di masa pandemi covid-19 tidak semua pendidik memanfaatkan teknologi yang ada dalam menunjang proses pembelajarannya di kelas. Keterampilan memanfaatkan teknologi pada pendidik dalam melaksanakan pembelajaran di masa pandemi covid-19 sangatlah penting untuk meningkatkan pemahaman peserta didik terhadap materi yang disampaikan. Terdapat berbagai macam keterampilan yang dapat diterapkan oleh pendidik untuk melaksanakan 
pembelajaran di kelas, salah satunya adalah pemanfaatan media dalam pembelajaran. Media pembelajaran dapat menjadikan sebuah perantara yang cukup efektif bagi pendidik kepada peserta didik dalam menyampaikan sebuah materi, agar materi itu dapat sampai dan mudah untuk dipahami oleh peserta didik dengan baik.

Pembelajaran era digital saat ini menuntut dosen untuk kreatif dan inovatif dalam proses pembelajaran. Selain itu pembelajaran harus terjadi interaksi yang berkualitas dan efektif (Darmuki \& Hidayati, 2019; Darmuki \& Hariyadi, 2019) serta memicu motivasi mahasiswa dalam kegiatan pembelajaran (Darrmuki dkk., 2017) sehingga terjadi proses transfer informasi pengetahuan ke mahasiswa (Darmuki dkk., 2018). Kreatifitas dan alternatif dari dosen dituntut untuk memaksimalkan pembelajaran yang efektif (Darmuki, 2020; Hidayati \& Darmuki, 2021; Hasanah dkk., 2021).

Belajar merupakan suatu proses, tindakan, dan perilaku yang kompleks yang dialami oleh peserta didik (Hariyadi \& Darmuki, 2019: 281). Belajar dikatakan kompleks karena dipengaruhi oleh banyak faktor baik itu dari internal maupun dari eksternal peserta didik. Faktor internal dari peserta didik salah satunya adalah minat terhadap proses belajar. Minat adalah kekuatan mental yang mendorong adanya keinginan untuk mengarahkan sikap dan perilaku individu untuk aktif belajar (Darmuki dan Hidayati, 2019: 9). Faktor eksteral dari peserta didik seperti bahan materi, lingkungan belajar, sarana prasaran belajar dan lain-lain. Mahasiswa sebagai subjek yang terlibat dalam kegiatan belajar akan mengalami suatu proses belajar. Proses belajar ini ditandai dengan keaktifan mahasiswa di dalam pembelajaran. Keaktifan pembelajaran ini terlihat dari keterlibatan fisik maupun mental mahasiswa dalam proses pembelajaran. Menurut (Darmuki \& Hariyadi, 2019: 257; Aisyah dkk., 2020), keaktifan yaitu suatu kegiatan/segala sesuatu yang menunjukkan adanya keterlibatan fisik maupun mental seseorang dalam aktivitas tertentu.

Berdasarkan hasil observasi dan ulangan harian hasil belajar managemen pemasaran mahasiswa masih rendah. Hal ini menunjukkkan bahwa pemahaman mahasiswa terhadap materi yang sudah disampaikan dosen masih belum maksimal. Proses pembelajaran juga belum menunjukka keaktifan mahasiswa. Mahasiswa masih bingung dan pembelajaran yang dilakukan secara online membosankan dan monoton. Banyak mahasiswa yang cuek terlihat dari tatap maya yang ditunjukkan melalui camera mahsing-masing mahasiswa. Ada beberapa mahasiswa juga cuek dan asik sendiri dengan situasi di tempatnya masing-masing tanpa melihat materi yang disampaikan dosen melalui tatap maya. Rendahnya keaktifan mahasiswa juga terlihat dari apa yang ditanyakan dosen ketika proses pembelajaran berlangsung.

Upaya yang dapat dilakukan untuk memperbaiki pembelajaran tersebut salah satunya menggunakan media video. Melalui media video yang dekat dengan kehidupan mahasiswa diharapkan dapat menarik minat mahasiswa untuk mempelajari materi managemen pemasaran sehingga dapat memunculkan motivasi mahasiswa untuk belajar managemen pemasaran. Media video menurut Ivers, \& Baron (2002) jenis media yang mengandung unsur gambar yang dapat dilihat dan dapat didengarkan. Video merupakan salah satu bentuk dari media audio visual. Video merupakan gabungan dari gambar dan suara yang tersusun menjadi satu file. Dalam pembelajaran secara daring, video ini dapat diunggah melalui media sosial sehingga peserta didik dapat menonton dan mengunduhnya secara mudah. Video pembelajaran ini memiliki banyak manfaat salah satunya meningkatkan motivasi belajar (Cakir, 2006). Motivasi merupakan kemauan atau keinginan seseorang secara sadar atau tidak sadar untuk mencapai tujuan tertentu (Hariyadi \& Darmuki, 2019; Wiji Astutik, dkk,. 2021). Sementara belajar merupakan kegiatan memperkaya intelektual, pengalaman, pengetahuan.

Media pembelajaran merupakan segala sesuatu yang dapat dipergunakan untuk merangsang pikiran, perasaan, perhatian dan kemampuan atau ketrampilan pembelajar sehingga mendorong terjadinya proses belajar (Darmuki \& Hidayati., 2019; Madhuri, 2013; Hidayati dkk., 2019; Ayun Sirosa, dkk., 2021 ). Media pembelajaran adalah segala sesuatu yang dapat digunakan untuk menyalurkan pesan dari pengirim ke penerima sehingga merangsang pikiran, perasaan, perhatian dan minat serta kemauan 
peserta didik sedemikian rupa sehingga proses belajar terjadi dalam rangka mencapai tujuan pembelajaran sehingga efektif (Hidayati dkk., 2019; Mutar, 2009; Hariyadi, A. 2018). Menurut beberapa pendapat di atas maka dapat disimpulkan bahwa media pembelajaran adalah proses segala sesuatu yang dapat dipergunakan untuk menyampaikan isi/materi pembelajaran guna untuk merangsang pikiran, perasaan, perhatian dan kemampuan atau ketrampilan pembelajar sehingga dapat mendorong terjadinya proses belajar. Langkah-langkah pemanfaatan video dalam proses pembelajaran hendaknya memperhatikan hal-hal sebagai berikut: 1) program video harus dipilih agar sesuai dengan tujuan pembelajaran; 2) pendidik harus mengenal program video yang tersedia dan terlebih dahulu melihatnya untuk mengetahui manfaatnya bagi pembelajaran; 3) sesudah program video dipertunjukkan, perlu diadakan diskusi, yang juga perlu dipersiapkan sebelumnya. Di sini peserta didik melatih diri untuk mencari pemecahan masalah, membuat dan menjawab pertanyaan; 4) adakalanya program video tertentu perlu diputar dua kali atau lebih untuk memperlihatkan aspek-aspek tertentu; 5) agar peserta didik tidak memandang program video sebagai hiburan belaka, sebelumnya perlu ditugaskan untuk melihat bagian-bagian tertentu; 6) sesudah itu dapat dites berapa banyakkah yang dapat mereka tangkap dari program video itu (Mayer, 2001).

\section{Metode Penelitian}

Jenis penelitian tindakan kelas ini menggunakan pendekatan deskriptif kualitatif. Penilitan tindakan kelas ini terdiri dari dua siklus yaitu tindakan siklus 1 dan tindakan siklus 2. Masing-masing siklus terdiri dari perencaaan, pelaksanaan, pengamatan, dan refleksi. Penelitian tindakan kelas ini dilaksanakan pada mahasiswa kelas A Prodi Managemen STIE Semarang Tahun Akademik 2020/2021. Jumlah mahasiswa kelas A ada 30 mahasiswa dengan rincian 9 laki-laki dan 21 perempuan. Objek penelitian ini adalah proses pembelajaran managemen pemasaran yang dilakukan secara daring menggunakan zoom. Pembelajaran ini direkam dengan menggunakan fasilitas record yang tersedia di zoom.

Tehnik pengumpulan data penelitian ini menggunakan wawancara, observasi, dokumentasi, dan tes. Metode pengumpulan data yang peneliti gunakan adalah metode observasi, dokumentasi, dan wawancara. Jenis metode observasi yang peneliti gunakan adalah observasi tanpa partisipasi atau nonpartisipan. Metode observasi tanpa partisipasi atau nonpartisipasi artinya peneliti memang hadir dalam kegiatan, tetapi peneliti tidak aktif dalam kegiatan yang dilakukan oleh subjek penelitian. Singkatnya, peneliti hanya mengamati dan menganalisis penggunaan media video dalam pembelajaran managemen pemasaran.

Dalam penelitian ini, metode dokumentasi digunakan untuk mendapatkan data dari kontrak kuliah . Dari kontrak kuliah tersebut, peneliti dapat mengetahui perencanaan dosen dalam mengajar. Perlu peneliti pertegas bahwa metode dokumentasi ini tidak peneliti gunakan untuk menjawab rumusan masalah yang telah dirumuskan. Akan tetapi metode dokumentasi ini peneliti gunakan untuk mengumpulkan data berupa kontrak kuliah yang digunakan oleh dosen di dalam melakukan pembelajaran keterampilan menulis.

Adapun jenis wawancara yang digunakan dalam penelitian ini adalah wawancara tidak berstruktur, karena dengan jenis wawancara ini peneliti bebas menanyakan apa saja namun tetap berpedoman pada data yang akan dikumpulkan. Penggunaan jenis wawancara ini, dimaksudkan untuk memperoleh data yang lebih akurat dan mendalam dari subjek penelitian sehingga subjek tidak terikat dengan jawaban "Ya" atau "Tidak". Kebaikan wawancara tidak berstruktur adalah responden tidak menyadari sepenuhnya bahwa ia sedang diwawancarai. Wawancara ini akan peneliti lakukan terhadap dosen managemen pemasaran tersebut yang akan diwawancarai oleh peneliti terkait rumusan masalah yang telah diuraikan secara virtual. 
Teknik analsis data ini menggunakan teknik analisis interaktif yang terdiri dari tiga komponen yaitu pengelompokkan data, penyajian data, dan penarikan simpulan. Data penelitian yang telah di dapat dari lapangan dikelompokkan sesuai dengan permasalahan selanjutnya dipilah-pilah data yang sesuai dengan yang dibutuhkan. Setelah data dikelompokkan kemudian data yang sudah sesuai dengan permasalahan disajikan untuk menjawab masing-masing rumusan masalah dan dianalisis sesuai kajian teori yang digunakan. Data yang sudah disajikan sesuai dengan permasalahan dan dikaji sesuai kajian teori kemudian disimpulkan berdasarkan temuan penelitian.

\section{Hasil dan Pembahasan}

Penelitian yang dilakukan di Prodi Managemen, bertujuan untuk meningkatkan pemahaman konsep managemen pemasaran. Penelitian dilaksanakan mulai dari pratindakan, tindakan siklus I, dan tindakan siklus II. Media yang dipilih dalam penelitian ini adalah media audiovisual berupa media video. Dari penelitian ini dapat dijelaskan bahwa penggunaan media video dapat meningkatkan pemahaman konsep managemen pemasaran mahasiswa kelas A di Prodi Managemen STIE Semarang. Berdasarkan kegiatan pembelajaran di pra siklus sebelum menggunakan media video mahasiswa yang tuntas hanya $60 \%$ atau 18 orang dan belum tuntas 12 orang. Hasil dari tindakan siklus I, persentase ketuntasan mahasiswa 80\%, dari 30 mahasiswa, sebanyak 24 mahasiswa mencapai ketuntasan. Mahasiswa yang belum mencapai ketuntasan pada siklus 1 sebanyak 6 mahasiswa. Keenam mahasiswa yang belum mencapai ketuntasan karena mereka belajar dengan kurang serius. Dosen telah memberi motivasi agar meningkatkan semangat dalam belajar. Setelah tindakan siklus II naik menjadi $90 \%$. Ketuntasan belajar, sebanyak 27 mahasiswa dapat mencapai batas ketuntasan, dan 3 mahasiswa belum mencapai ketuntasan. Ketiga mahasiswa yang belum mencapai ketuntasan, disebabkan karena memang mahasiswa berjenis slow learner yang membutuhkan tambahan waktu dan perhatian khusus dalam mendampingi mereka belajar. Kriteria keberhasilan penelitian telah tercapai, tindakan sampai siklus II karena telah mencapai ketuntasan $90 \%$.

Tabel 1. Hasil Belajar Pra siklus, Siklus 1, dan Siklus 2

\begin{tabular}{cccc}
\hline Tindakan & Pra Siklus & Siklus 1 & Siklus 2 \\
\hline Tuntas & $60 \%(18)$ & $80 \%(24)$ & $90 \%(27)$ \\
Belum Tuntas & $40 \%(12)$ & $20 \%(6)$ & $10 \%(3)$ \\
Jumlah Total & $100 \%$ & $100 \%$ & $100 \%$ \\
\hline
\end{tabular}

Dari tabel di atas dapat disimpulkan jumlah mahasiswa yang menerima pembelajaran materi managemen pemasaran mengalami peningkatan hasil belajar, dari pra siklus sebesar $61 \%$ meningkat terutama pada tindakan siklus 1 yang mengalami kenaikan relatif tinggi mencapai $80 \%$ mahasiswa yang tuntas, begitu juga pada siklus 2 ada peningkatan ketuntasan $90 \%$. Peningkatan hasil belajar pada mahasiswa dipengaruhi oleh penggunaan media video yang dapat meningkatkan hasil belajar mahasiswa.

Terjadinya peningkatan hasil belajar ini disebabkan oleh beberapa hal, yang dipaparkan sebagai berikut. (1) media video pembelajaran dalam proses pembelajaran memberikan suasana baru yang menjadikan kegiatan pembelajaran lebih menyenangkan. Mahasiswa tidak lagi merasa bosan karena hanya menerima materi dari komunikasi verbal dalam tatap maya yang disampaikan oleh dosen. Dalam menerima materi yang disajikan melalui media video pembelajaran, perhatian mahasiswa lebih terfokus; (2) media video pembelajaran yang berupa video animasi mampu menampilkan atau menyajikan objek yang abstrak menjadi objek konkrit dan nyata. Selain itu, materi-materi yang secara fisik tidak dapat dibawa ke dalam kelas guna menunjang proses pembelajaran dapat ditampilkan melalui video pembelajaran. Hal ini sesuai dengan pendapat Darmuki dkk. (2019) bahwa makna dan tujuan dari penggunnaan media dimana pembelajaran akan lebih menyenangkan apabila pada proses pembelajaran 
dosen mampu menyajikan materi yang secara fisik tidak dapat dibawa ke dalam kelas; (3) media video pembelajaran menampilkan suara (audio) dan gambar (visual). Hal ini membantu mahasiswa dalam memahami materi pembelajaran. Setiap mahasiswa memiliki cara-cara yang berbeda dalam menerima dan memahami materi yang diajarkan. Ada mahasiswa yang hanya dapat menerima dan memahami materi ajar dengan mendengar (audio), dengan melihat (visual), dan ada juga mahasiswa yang hanya mampu menerima dan memahami materi ajar dengan mendengar dan melihat materi ajar (audio visual). (4) adanya reinforcement yang diberikan dosen terhadap kerja mahasiswa juga berkontribusi terhadap peningkatan motivasi dan aktivitas mahasiswa yang secara langsung mempengaruhi peningkatan hasil belajar mahasiswa. Bentuk penguatan yang diberikan dosen, baik berupa tepuk tangan, poin, dan hadiah kecil lainnya. Ini menjadi salah satu pemacu motivasi mahasiswa untuk lebih aktif dalam mengikuti proses pembelajaran dan berdampak positif terhadap pelaksanaan pembelajaran di kelas serta adanya kompetisi antar mahasiswa untuk memperoleh penghargaan dari dosen sebanyakbanyaknya. Pendapat ini didukung oleh pendapat Smaldino dkk. (2002: 95) bahwa, "dosen harus dapat merangsang dan memberikan dorongan serta reinforcement untuk mendinamisasi potensi mahasiswa, menumbuhkan motivasi dan daya kreativitas sehingga terjadi dinamika dalam proses belajar mengajar". Ini berarti, pemberian reinforcement sangat penting dalam pelaksanaan pembelajaran di kelas.

Berdasarkan data pada pra siklus, siklus I dan siklus II dapat disimpulkan bahwa pembelajaran menggunakan media video dapat meningkatkan pemahaman mahasiswa dalam materi managemenn pemasaran mahasiswa kelas A Prodi Managemen STIE Semarang. Dengan media video ini selain meningkatkan pemahaman juga meningkatkan kualitas pembelajaran daring serta minat siswa selama pembelajaran dan juga dapat meningkatkan hasil belajar mahasiswa. Hal ini sesuai dengan pendapat Darmuki \& Hidayati (2019) yang menyatakan bahwa pemanfaatan media yang relevan di dalam kelas dapat mengoptimalkan proses pembelajaran. Kemudian menurut Hidayati dkk. (2019) media pembelajaran adalah salah satu alat bantu mengajar bagi dosen untuk menyampaikan materi pembelajaran, meningkatkan kreatifitas mahasiswa dan meningkatkan perhatian mahasiswa dalam proses pembelajaran.

Kekurangan dari pemanfaatan media video ini ialah tempat yang kurang medukung dan kekurangan fasilitas dapat membuat perhatian mahasiswa terganggu dan terhambat. Berbeda dengan kelas sebelum tindakan yang tidak memanfaatkan media video. Keadaan kelas tidak kondusif, karena mahasiswa tidak fokus dengan materi managemen pemasaran yang telah disampaikan dosen tanpa mengggunakan media video. Penerapan materi managemen pemasaran yang dilakukan tanpa mengggunakan media video terlihat relatif sangat membosakan, namun tidak sedikit mahasiswa yang fokus dalam proses pembelajaran tanpa menggunakan media video. Perbandingan penggunaan media pembelajaran video dengan tidak memnfaatkan media video dapat dilihat dari kondisi proses pembelajaranya, pada pembelajaran dengan menggunakan media video suasana kelas lebih tenang daripada kelas yang tidak menggunakan media video pada saat pra siklus.

\section{Kesimpulan}

Berdasarkan hasil penelitian dan pembahasan di atas, dapat disimpulkan bahwa pada siklus I, dari 30 mahasiswa, nilai yang berada di bawah KKM adalah 6 mahasiswa (20\%), sedangkan yang di atas KKM adalah 24(80\%). Pada siklus II, dengan adanya perbaikan pembelajaran menggunakan media video, semakin meningkatkan pemahaman konsep managemen pemasaran mahasiswa. Nilai mahasiswa yang berada di bawah KKM 3 mahasiswa (10\%), sedangkan yang di atas KKM adalah 27 mahasiswa $(90 \%)$. Berdasarkan data di atas penggunaan media video telah dapat meningkatkan pemahaman konsep managemen pemasaran pada mahasiswa kelas A di Prodi Managemen STIE Semarang Tahun Akademik 2020/2021. 


\section{Daftar Pustaka}

Aisyah, Siti Umi Nur, Sarjono, Ahmad Hariyadi (2020). Penerapan Motode Pembelajaran Resitasi dan Diskusi untuk Meningkatkan Hasil Belajar Mata Pelajaran Ekonomi Pokok Bahasan Perpajakan pada kelas XI IPS MA Abu Dzarrin Kendal Bojonegoro Tahun Ajaran 2019/2020. Lentera Vol 13 (2). 305-314.

Ayun Sirosa, M., Sarjono, Ahmad Hariyadi (2021). Pengaruh Fasilitas Belajar dan Lingkungan Pondok Pesantren Al Husna Terhadap Prestasi Belajar Mata Pelajaran IPS Siswa Kelas VII C di MTs Islamiyah Malo Tahun Ajaran 2019/2020. Aksara Vol. 7(1). 29-36.

Cakir, I. (2006). The use of video as an audio-visual material in foreign language teaching classrooms. The Turkish Online Journal of Educational Technology, 5(4), 67-72.

Darmuki, Agus. (2020). Upaya Meningkatkan Kemampuan Berbicara Mahasiswa Menggunakan Media Aplikasi Google Meet Berbasis Unggah Tugas Video Di Youtube Pada Masa Pandemi Covid-19. Jurnal Educatio FKIP UNMA, Vol 6(2),655-661.

Darmuki, A. \& Ahmad Hariyadi. (2019). Eksperimentasi Model Pembelajaran Jucama Ditinjau Dari Gaya Belajar Terhadap Prestasi Belajar Mahasiswa Mata Kuliah Berbicara Di Prodi PBSI IKIP PGRI Bojonegoro. Kredo. 3(1), 62-72.

Darmuki, A., Ahmad Hariyadi. 2019. Peningkatan Keterampilan Berbicara Menggunakan Metode Kooperatif Tipe Jigsaw pada Mahasiswa PBSI Tingkat IB IKIP PGRI Bojonegoro Tahun Akademik 2018/2019. Kredo. 2(2), 256-267.

Darmuki, A. \& Hidayati N.A. (2019). An Investigation of The Cooperative Learning Using Audio Visual Media in Speaking Skill Subject. ICSTI. 121-126.

Darmuki, A. \& Hidayati, N.A. (2019). Peningkatan Kemampuan Berbicara Menggunakan Metode Kooperatif Tipe NHT pada Mahasiswa Tingkat I-A Prodi PBSI IKIP PGRI Bojonegoro Tahun Akademik 2018/2019. Jurnal Pendidikan Edutama. Vol. 6(2), hlm 9-18.

Darmuki, A., Andayani, Joko Nurkamto, Kundharu Saddhono. (2017). Cooperative, Synectics, and CTL Learning Models Toward Speaking Ability Viewd from Students Motivation. Proceeding International Conference on Intellectuals'Global Responsibility (ASSEHR). Vol. 125, 75-79.

Darmuki, A., Andayani, Joko Nurkamto, Kundharu Saddhono. (2017). Evaluating InformationProcessing-Based Learning Cooperative Model on Speaking Skill Course. Journal of Language Teaching and Reasearch. 8(1) pp. 44-51.

Darmuki, A., Andayani, Joko Nurkamto, Kundharu Saddhono. (2018). The Development and Evaluation of Speaking Learning Model by Cooperative Approach. International Journal of Instruction. 11(2), 115-128.

Darmuki, A., Ahmad Hariyadi, Nur Alfin Hidayati. (2020). Peningkatan Minat dan Hasil Belajar Keterampilan Berbicara Menggunakan Metode Mind Map pada Mahasiswa Kelas IA PBSI IKIP PGRI Bojonegoro Tahun Akademik 2019/2020. Kredo. 3 (2), 263-276.

Darmuki, A., Hariyadi, A., \& Hidayati, N. A. (2021). Peningkatan Kemampuan Menulis Karya Ilmiah Menggunakan Media Video Faststone di Masa Pandemi COVID-19.Jurnal Educatio FKIP UNMA, 7(2), 389-397.

Hariyadi, A., Agus Darmuki. (2019). Prestasi dan Motivasi Belajar dengan Konsep Diri. Prosiding Seminar Nasional Penguatan Muatan Lokal Bahasa Daerah sebagai Pondasi Pendidikan Karakter Generasi Milenial. PGSD UMK 2019, 280-286.

Hariyadi, Ahmad. 2018. User Of Smart Ladder Snanke Media to Improve Stundent Learning Outcomes Of IV Grade Students of State Elementary School I Doropayung Pancur Rembang. Refleksi Edukatika. Vol. 9 (1), 107-111.

Hasanah Uswatun , Sarjono , Ahmad Hariyadi. (2021). Pengaruh Model Problem Based Learning Terhadap Prestasi Belajar IPS SMP Taruna Kedung Adem. Aksara. Vol. 7(1). 43-52. 
Hidayati, N. A., \& Darmuki, A. (2021). Penerapan Model Auditory Intellectually Repetition (AIR) untuk Meningkatkan Kemampuan Berbicara Pada Mahasiswa .Jurnal Educatio FKIP UNMA, 7(1), 252-259.

Hidayati, Nur A., Herman J. W., Retno W., Suyitno. (2019). Meanings and Values of Local Wisdom in Sura Salvation Ceremony of Samin Jepang Community, Indonesia for Audio Visual TechnologyBased Learning. EUDL. DOI:10.4108/eai.19-10-2018.2282549.

Ivers, K., \& Baron, A. (2002). Multimedia Project in Education. Santa Barbara: ABC-CLIO LLC.

Madhuri, J. N. (2013). Use of Audio Visual Aids in Teaching and Speaking. Research Journal of English Language and Literature, 1(3), 108-122.

Mutar, S.S (2009). The effect of using technical audio-visual aids on learning technical English language at technical institutes. Journal for Academic Studies, 8(15), 1-12.

Mayer, R. E. (2001). Multimedia Learning. Cambridge, UK: Cambridge University Press.

Smaldino, S. E., Russell, J. D., Heinich, R., \& Molenda, M. (2002). Instructional Technology and Media for Learning (8th Ed.). Upper Saddle River, NJ: Pearson.

Wiji Astutik, S. Sarjono, Ahmad Hariyadi. (2021). Penerapan Model Pembelajaran Group Investigation untuk Meningkatkan Aktifitas dan Hasil Belajar IPS Siswa kelas VII SMPN 1 Senori Tahun Ajaran 2019/2020. Aksara. Vol. 7(1). 37-42. 